\title{
Environmental aspects of Micro, Small and Medium Enterprises (MSMEs)
}

\author{
Hartomi Maulana ${ }^{1}$, Khoirul Umam², Rahma Yudi Astuti ${ }^{3}$, Eko Nur Cahyo ${ }^{4}$, and Roghiebah \\ Jadwa Faradisi ${ }^{5}$ \\ \{mhartomi@unida.gontor.ac.id ${ }^{1}, \underline{\text { khoirulumam@unida.gontor.ac.id }}^{2}$, rahmayudi67@unida.gontor.ac.id $^{3}$, \\ eko.nurcahyo@unida.gontor.ac.id ${ }^{4}$, rrjfaradisi29@gmail.com ${ }^{5}$.
}

Universitas Darussalam Gontor, Ponorogo, Indonesia

\begin{abstract}
Even though growing literature on environmental practices of large companies, the role of MSMEs remains less attention. While MSMEs dominate most firms in Indonesia, they will indirectly affect ecological issues. This study looks at the extent to which MSMEs involve in environmental practices. Specifically, the study attempts to assess the firm's size and firm's business sector and its influence on ecological aspects. Primary data collected by self-administered questionnaires with a sample of 250 respondents from selected MSMEs owners in East Java is carried out. The finding of the study revealed that firms size positively affect the entrepreneur's involvement in environmental practices. It indicates that greater firm size in the level of MSMEs is more likely to involve in environmental practices. Moreover, the firm's business sector is also found to have positive influence entrepreneur's engagement in environmental practice. The study suggests MSMEs particularly consumer goods and restaurant sectors are more closely monitored by the owner or manager which make them more likely to undertake environmental strategies.
\end{abstract}

Keywords: Micro, small and medium enterprises (MSMEs), Environmental, Entrepreneurs, East Java.

\section{Introduction}

There has been a growing concerning on the business that plays a role in preserving the environment since the 1960s [1]. Even though growing literature on environmental practices of the significant industry, the role of MSMEs remains less attention [2]. It ignores the substantial impact of MSMEs on the natural environment which may contribute a significant proportion of pollution in the world [3].

There is a need to overcome the environmental impact of MSMEs with having a better understanding of what motives behind individual MSMEs in involving in green practices. Often, rules and policies issued are based on perception from the large business which is always perceived representing MSMEs [4].

In Indonesia, the term of microenterprise is if it employs less than five workers, small business employs less than 20 workers while medium enterprises operate between 20 and 99 workers (Sembiring, 2008). While it has been long recognized to have a significant contribution to the national economy, their influence on environmental practice has only lately been carried out.

Thus, the purpose of this study is to look at the extent to which MSMEs in East Java, Indonesia involve in environmental practices. Specifically, the study attempts to assess the firm's size and firm's business sector and its influence on ecological aspects. The importance of the research is to accommodate the market and policymakers on MSMEs to reduce the environmental impact of their operations. The study 
goes beyond the predominant focusing on large firms but concerning small firms [1]. Also, there is little empirical evidence to study environmental practices of MSMEs particularly in Indonesia.

\section{Literature Review}

This section reviews the literature relating to environmental aspects and large business and MSMEs. It also discusses developing the hypothesis.

\subsection{Large business and environment}

The environmental practice has mainly been conducted in a large market. Sustainable development and corporate social responsibility (CSR) concepts are predominantly used by large companies involved in environmental practices [2]. Sustainable development can be defined as "meeting the needs of current generations without compromising on the ability of future generations to meet their own needs"'[5]. Related to the business sector, CSR refers to a fast move beyond fulfillment and involves actions that emerge to advance a social cause [2]. CSR empirical mostly focus on large business [4], and the result of this study cannot be generalized to small business. There are several advantages when large business involves environmental practices [3]. While large companies have a greater capability to reach benefit from environmental practice due to economies of scale, they have more resources, the greater magnet to affect regulation and policy. Accordingly, voluntary involvement in environmental practice can be viewed as an excellent opportunity for large businesses [3].

\subsection{MSMEs and environment}

MSMEs are the largest business sector in every country and provide the most economic output in the world [3]. In Indonesia, about 98.7 percent of the total number of businesses (over 57 million enterprises) are microenterprises [6]. It is followed by small enterprises (1.13 percent) then medium-sized (0.09). Microenterprises (which employs less than five workers) have about 104 million employees or 88.90 percent of the total workforce in the business sector. It generates an estimated 36.90 percent of Indonesia's GDP (Ministry of Cooperative and MSMEs, 2017). Therefore, it indicates that MSMEs have to be involved in the environmental program while any real change may happen. While much of the literature has focused on how large businesses affect environmental practices, few empirical studies have been conducted on the impact of MSMEs on their involvement in environmental practice particularly in Indonesia.

Empirical studies on the role of MSMEs in the involvement of environmental practice in various countries carried out in this section. Redmond et al. examined the small business's environmental impact in terms of waste, energy, and water [3]. A survey was employed and distributed to 466 small businesses in Australia. The study revealed that small businesses affect the environment in terms of waste disposal. The finding of the study also showed that their environmental management practices concerning waste, energy, and water were found to differ depending on the local context in which the small businesses operate

Chen and Chang (2011) studied the effects of environmental commitments and green intangible assets on green competitive advantages of companies in Taiwan [7]. To achieve the objective, the data collected from 134 respondent and analyzed by using SEM. The results showed that environmental commitments and green intangible assets are positively associated with green competitive advantages. Furthermore, this study found that environmental commitments, green intangible assets, and green competitive advantages of small \& medium enterprises (SMEs) are all less than those of large enterprises in Taiwan. Hence, there is the advantage of firm size concerning environmental commitments, green intangible assets, and green competitive advantages in Taiwan.

Meanwhile, Hoogendoorn et al. investigated the influence of firm characteristics on SMEs' environmental behavior [2]. By using unique data for almost 8,000 SMEs across 12 sectors in 36 countries, the study indicated that different characteristics have different influences on both types of environmental 
practices such as the type of customers served. Firm size was found to influence their environmental practice in terms of greening process. Finally, this study also showed that SMEs active intangible sectors and received financial support are more involved in either type of environmental practices

Another study conducted by Zuraidah et al. (2014) that assessed key causal linkages of proactive environmental practices of small and medium enterprises (SMEs) [8]. While using the survey data collected from 232 Malaysian SMEs, the structural equation modeling (SEM) was employed to test the hypotheses. The results indicated that decisions on environmental practices are influenced significantly by interactions between stakeholders but notably in different ways. While customers and employees' involvements are targeted at process-based changes, senior managers are interested in internal management improvements. Suppliers' interactions, on the other hand, influence SMEs to improve operations for product and process-based changes at the same time.

\subsection{Hypothesis}

Firm size. Some studies show that firm size affects the environmental practices of businesses [7], [9], [2]. In their study, Chen and Chang (2011) revealed that firm size was found to have associated with green competitive advantages[7]. It indicates that environmental commitments, green intangible assets, and green competitive advantages of small \& medium enterprises (SMEs) are all less than those of large enterprises. Similarly, Uhlaner et al. (2012) found that firm size predicted an SME's level of engagement in selected environmental management practices [9]. In line with this finding, Hoogendoorn et al., (2014) that studied about driving small and medium-sized enterprises (SMEs) to engage in environmental practices showed that substantial size influence SMEs engagement in greening processes [2]. Supporting this, it presents the following hypothesis for the involvement of MSMEs in environmental practices.

$H 1=$ Firm size is positively associated with the involvement in environmental practices . MSMEs' business sector. In their study, Uhlaner et al. (2012) found that endogenous factors such as tangibility of sector have an impact on SME's engagement in environmental management practices [9]. This study indicates although tangibility of the business sector has a high impact on the environment, firms in more physical sectors are likely to be closely monitored and, thus, be more aware of environmental issues. Another study by Hoogendoorn et al. (2014) resulted that there is a positive relationship between sector tangibility and SMEs' environmental behavior [2]. Based on this finding, this study proposes the following hypothesis:

$H 2=$ MSME's business sector is positively related to involvement in environmental practices.

\section{Methodology}

Quantitative approach used to achieve the objectives. Data collection technique used is survey method by using a questionnaire given to MSMEs owners-managers in Indonesia province of East Java. Firm size is measured based on total asset (excluding building and land) while the business sector is categorized into three sectors namely, consumer goods, trading/services, and restaurant/food stall are business sectors.

Moreover, the items of the survey questionnaire of environmental practice were adapted from the relevant variables [9], [2]. Each item of the questionnaire is measured using a scale where one stands for strongly disagree, 3 for somewhat agree and five stands for strongly agree. The technique of sampling used in the study is convenience sampling.

Before collecting the actual data, a pilot test was conducted to ensure the internal consistency of the questions in the questionnaire [10]. Their feedbacks were incorporated, and the questionnaire was revised accordingly. Data collection is completed for six months with usable responses of 250 from the total 400 distributed questionnaires (62 percent response rate). In this paper, multiple regression used as technique analysis. 


\section{Results and Discussion}

Two sections (demographic information and environmental aspects) of the questionnaires are discussed based on descriptive statistics.

\subsection{Demographic}

As presented in Table 1, most respondents (53.2 percent, $\mathrm{N}=133$ ) are owners of the MSMEs. In terms of age, 40-49 years dominates the owner of MSMEs with recording 37,6 percent $(\mathrm{N}=94)$. About 62.8 percent $(\mathrm{N}=157)$ graduated from secondary school, 16.8 percent $(\mathrm{N}=42)$ and 14 percent $(\mathrm{N}=35)$ with a primary school and first degree, respectively. Interestingly, all surveyed MSMEs are Muslim (100 percent, $\mathrm{N}=250$ ). In terms of MSMEs of the business sector, trading and services are more dominant (43.6 percent), followed by consumer goods ( 38.8 percent), the restaurant ( 26.8 percent)

With regard to total sales, less than 300 million documented by 205 respondents ( 81.6 percent), indicating classified as microenterprises, then between 300 million and 2.5 billion noted by 42 respondents (16.8 percent), indicating classified as small enterprises and ranging between 2.5 billion and 50 billion accounted by 4 respondents (1.6 percent), indicating classified as medium enterprises. Regarding asset, this study considers a various size of assets (ranging between Rp1 million and Rp10 billion) with an average of Rp 455 million. Accurately, it records that 67.2 percent $(\mathrm{N}=167)$ have assets between $\mathrm{Rp} 1$ million and $\mathrm{Rp} 50$ million and 25.2 percent $(\mathrm{N}=63)$ have assets between Rp50 million and Rp500 million. About 7.6 percent $(\mathrm{N}=19)$ have assets between Rp 500 million and $\mathrm{Rp} 10$ billion.

Table 1. Demographic

\begin{tabular}{llcc}
\hline \multicolumn{1}{c}{ Items } & & Frequency & Percent \\
\hline Status of the respondents & Owner & 133 & 53.2 \\
& Manager & 49 & 19.6 \\
& Owner \& Manager & 66 & 26.4 \\
Gender & Others & 2 & .8 \\
& Male & 123 & 49.2 \\
Marital Status & Female & 127 & 50.8 \\
& Single & 44 & 17.6 \\
Age & Married & 204 & 81.6 \\
& Others & 2 & .8 \\
& 20-29 & 45 & 18.0 \\
Education & $30-39$ & 84 & 33.6 \\
& $40-49$ & 94 & 37.6 \\
& 50 & 27 & 10.8 \\
& Non-Formal Education & 3 & 1.2 \\
& Primary School & 42 & 16.8 \\
Religion & Secondary School & 157 & 62.8 \\
Firm's business sector & Diploma & 9 & 3.6 \\
& First Degree & 35 & 14.0 \\
Number of working full time* & Postgraduate & 4 & 1.6 \\
in your business & Islam & 250 & 100.0 \\
& Consumer goods & 74 & 28.8 \\
& Trading/services & 109 & 43.6 \\
& Restaurants/food stall & 67 & 26.8 \\
& & & \\
& 6-19 & 238 & 95.2 \\
& & 9 & 3.6 \\
& & &
\end{tabular}




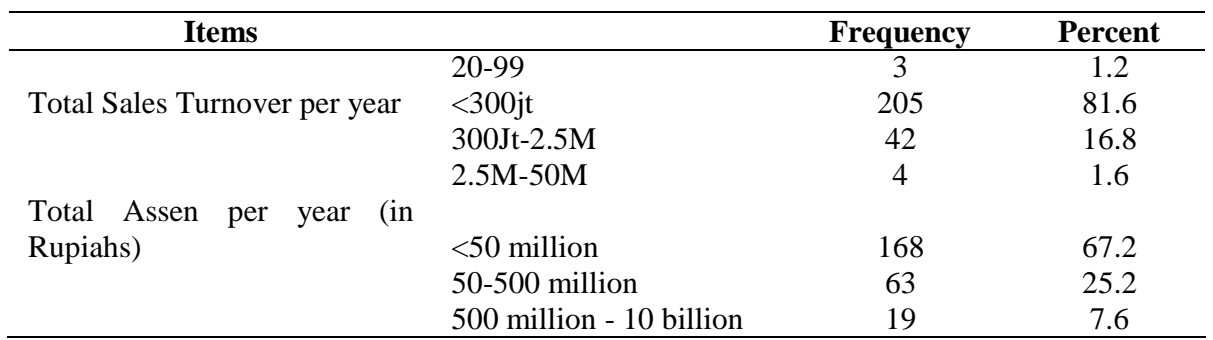

\subsection{Environmental aspects}

Reliability and validity analysis. To achieve reliable and valid results, measuring validity and reliability should be conducted in the undertaking of multiple regressions. The value of validity and reliability tests are in Table 2

Table 2. Reliability and Pearson correlation

\begin{tabular}{llccc}
\hline & & $\mathbf{1}$ & $\mathbf{2}$ & $\mathbf{3}$ \\
\hline 1. & Firm size & 1 & -.003 & $.164^{* * * *}$ \\
2. & Business of sector & -.003 & 1 & $.274^{* * * *}$ \\
3. & Environmental practices & $.164^{* * *}$ & $274^{* * * *}$ & $(.884)^{\mathrm{CA}}$ \\
\hline
\end{tabular}

***Significant level at $0.01, * *$ Significant at 0.05 , Cronbach's Alpha

As shown in Table 2, the environmental construct has attained the threshold value for reliability above 0.7 , while it shows significance $<0.01$ which is meeting the requirements of validity.

Multiple Regression. This study aims to look at the extent to which MSMEs involve in environmental practices. For the objective, two hypotheses have been constructed. Based on the results, all hypotheses are found to be statistically significant. Table 3 presents the statistical path result based on multiple regression.

Table 3. Linear Regression

\begin{tabular}{|c|c|c|c|c|c|}
\hline & Hypothesized Path & $\begin{array}{l}\text { Standardized } \\
\text { coefficient }\end{array}$ & $\begin{array}{l}\text { Std. } \\
\text { Error }\end{array}$ & Remark & Decision \\
\hline $\mathrm{H} 1$ & $\begin{array}{l}\text { Firm size } \rightarrow \\
\text { Environmental }\end{array}$ & .274 & .060 & $* * *$ & $\begin{array}{l}\text { Firm size and } \\
\text { environment are } \\
\text { significantly and } \\
\text { positively related } \\
\text { (Supported) }\end{array}$ \\
\hline $\mathrm{H} 2$ & $\begin{array}{l}\text { Business sector } \rightarrow \\
\text { Environmental }\end{array}$ & .165 & .000 & $* * *$ & \begin{tabular}{lr}
\multicolumn{2}{l}{ Business } \\
and environment \\
are & significantly \\
and & positively \\
related &
\end{tabular} \\
\hline
\end{tabular}

(Supported)

$* * *$ Significant level at $0.01, * *$ Significant at 0.05

$H 1=$ Firm size is positively associated with involvement in environmental practices 
we formulate the following hypothesis for greening processes

Finding of this study support this hypothesis. As presented in Table 2, the parameter estimate was 0.274 indicating if firm size goes up by one standard deviation, MSME's involvement in environmental practice goes up 0.274 . The result is statistically significant, practically relevant and logically justifiable. The results indicate that greater firm size in the level of MSMEs is more likely to involve in environmental practices. Due to their tiny size, microenterprises may be hard to allocate their investment in environmental aspects in the shake of economies of scale. They are less likely to involve in environmental practices as compared to small and mediumsized enterprises. This result is consistent with the study of Chen and Change (2011), Uhlaner et al. (2012) and Hoogendoorn et al. (2014) whose reached the same finding on the significant influence of firm size on environmental practice.

\section{$H 2=M S M E$ 's business sector is positively related to involvement in environmental practices.}

Similar to hypothesis 1 , the result of this study support hypothesis 2 . As a result, a significant relationship is found between MSME's business sector and environmental practice. Table 6 shows that the parameter estimate is .165 , indicating if MSME's business sector goes up by 1 , their engagement in environmental practice goes up .165. It points out that firms in consumer goods and restaurant sectors are more involved in environmental practices than firms in the trading or service sector. It may be due to these kinds of business sector have a high impact on the environment, firms in more consumer goods and restaurant sectors are likely to be closely monitored and, thus, be more aware of environmental issues. It is consistent with the findings of Uhlaner et al. (2012) and Hoogendoorn et al. (2014).

\section{Conclusion}

The primary purpose of this study was to examine at the extent to which MSMEs involve in environmental practices. The model hypothesized is categorized into two factors, namely firm size and firm's business sector which both influence MSME's engagement in environmental practices. This study found that firms size significantly affect MSME's involvement in environmental practices. The results show that greater firm size is more likely to involve in environmental practices. It may be due to their characteristics which are tiny size. As a result, they have difficulty in allocating their investment in environmental aspects. Similar to firm size, firm's business sector is also found to have significant influence MSME's engagement in environmental practice. It indicates that these sectors are aware they have a high impact on the environment. As a consequence, MSMEs in more consumer goods and restaurant sectors are likely to be closely monitored and, thus, be more aware of environmental issues. The study suggests MSMEs particularly firms in consumer goods and restaurant sectors are more closely monitored by the owner or manager which establish them more likely to adopt environmental strategies.

\section{References}

[1] A. Hoffman and P. Bansal, The Relevance of the Natural Environment for Corporate Social Responsibility Research. 2012.

[2] B. Hoogendoorn, D. Guerra, and P. van der Zwan, "What drives environmental practices of SMEs?," Small Bus. Econ., vol. 44, no. 4, pp. 759-781, 2015.

[3] J. Redmond, "The Impact Of Small Business On The Environment," 2008, no. 
November, pp. 1-16.

[4] F. Perrini, A. Russo, and A. Tencati, "CSR Strategies of SMEs and Large Firms. Evidence from Italy,” J. Bus. Ethics, vol. 74, no. 3, pp. 285-300, 2007.

[5] G. H. Brundtland, OurCommonFuture_BrundtlandReport_UN1987.pdf. Oslo: United Nation, 1987.

[6] D. Bellefleur, P. Tangkau, and Z. Murad, "A Snapshot of Indonesian Entrepreneurship and Micro, Small, and Medium Sized Enterprise Development For BAPPENAS and USAID Prepared by: SEBAR Team.” USAID, p. 94, 2012.

[7] Y.-S. Chen and C.-H. Chang, "Enhance environmental commitments and green intangible assets toward green competitive advantages: an analysis of structural equation modeling (SEM)," Qual. Quant., vol. 47, no. 1, pp. 529-543, 2013.

[8] R. Z. RM Rasi, A. Abdekhodaee, and R. Nagarajah, Stakeholders' involvements in the implementation of proactive environmental practices: Linking environmental practices and environmental performances in SMEs, vol. 25. 2014.

[9] L. M. Uhlaner, M. M. Berent-Braun, R. J. M. Jeurissen, and G. de Wit, "Beyond Size: Predicting Engagement in Environmental Management Practices of Dutch SMEs," J. Bus. Ethics, vol. 109, no. 4, pp. 411-429, 2012.

[10] U. Sekaran and R. Bougie, Research Methods For Business: A Skill Building Approach, 7th Edition. Wiley, 2016. 